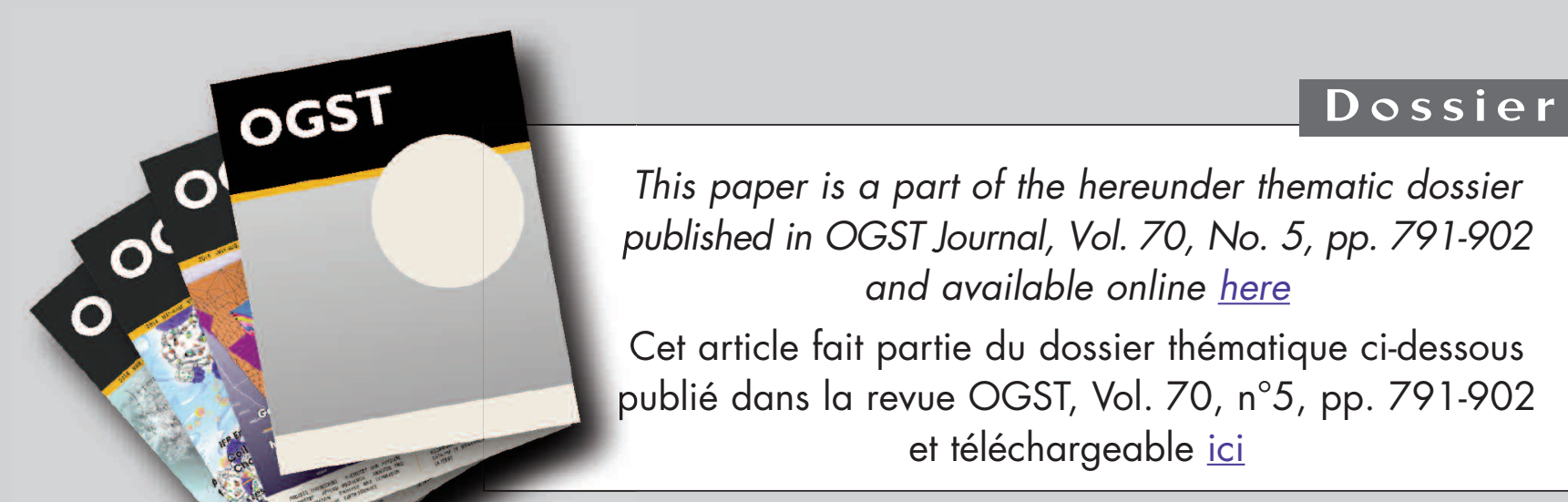

DOSSIER Edited by/Sous la direction de : D. Uzio

IFP Energies nouvelles International Conference / Les Rencontres Scientifiques d'IFP Energies nouvelles

$$
\begin{gathered}
\text { PHOTO4E - Photocatalysis for energy } \\
\text { PHOTO4E - Photocatalyse pour l'énergie }
\end{gathered}
$$

Oil \& Gas Science and Technology - Rev. IFP Energies nouvelles, Vol. 70 (2015), No. 5, pp. 791-902

Copyright (C) 2015, IFP Energies nouvelles

$791>$ Editorial

M. Fontecave, A. Fécant and D. Uzio

$799>$ Solar Production of Fuels from Water and $\mathrm{CO}_{2}$ : Perspectives and Opportunities for a Sustainable Use of Renewable Energy

Production solaire de carburants à partir de l'eau et de $\mathrm{CO}_{2}$ : perspectives et opportunités pour une utilisation durable de l'énergie renouvelable

R. Passalacqua, G. Centi and S. Perathoner

817 > Effect of Post-Synthesis Treatments on the Properties of ZnS Nanoparticles: An Experimental and Computational Study

Effet des traitements après-synthèse sur les propriétés de nanoparticules de ZnS : une étude expérimentale et computationnelle

E. Balantseva, B. Camino, A.M. Ferrari and G. Berlier

831 > Comparative Study on The Photocatalytic Hydrogen Production from Methanol over $\mathrm{Cu}_{-}, \mathrm{Pd}$-, Co- and Au-Loaded TiO

Étude comparative de production d'hydrogène par photocatalyse à partir de méthanol et à l'aide de différentes phases actives ( $\mathrm{Cu}, \mathrm{Pd}, \mathrm{Co}$ et Au) supportées sur TiO

P.P.C. Udani and M. Rønning

841 > Photocatalytic Conversion of Carbon Dioxide Using Zn-Cu-Ga Layered Double Hydroxides Assembled with Cu Phthalocyanine: Cu in Contact with Gaseous Reactant is Needed for Methanol Generation

Conversion photocatalytique du dioxyde de carbone par des hydroxydes doubles lamellaires de Zn-Cu-Ga promus par la phtalocyanine de Cu : nécessité du contact entre le Cu et le réactif gazeux pour la synthèse du méthanol

S. Kawamura, N. Ahmed, G. Carja and Y. Izumi
$853>$ Recyclable PhotoFuel Cell for Use of Acidic Water as a Medium Cellule photocombustible recyclable pour I'utilisation d'eau acide en tant que milieu

Y. Ogura, M. Yoshiba, and Y. Izumi

$863>$ Solar Hydrogen Reaching Maturity L'hydrogène solaire arrive à maturité

J. Rongé, T. Bosserez, L. Huguenin, M. Dumortier, S. Haussener and J.A. Martens

877 > Design of Compact Photoelectrochemical Cells for Water Splititing Conception de cellules photoélectrochimiques compactes pour la décomposition de l'eau

T. Bosserez, J. Rongé, J. van Humbeeck, S. Haussener and J. Martens

891 > Simultaneous Production of $\mathrm{CH}_{4}$ and $\mathrm{H}_{2}$ from Photocatalytic Reforming of Glucose Aqueous Solution on Sulfated Pd-TiO, Catalysts Production simultanée de $\mathrm{CH}_{4}$ et $\mathrm{H}_{2}$ par réformage photocatalytique d'une solution aqueuse de glucose sur un catalyseur Pd-TiO, sulfaté V. Vaiano, G. lervolino, G. Sarno, D. Sannino, L. Rizzo, J.J. Murcia Mesa, M.C. Hidalgo and J.A. Navío 


\title{
Simultaneous Production of $\mathrm{CH}_{4}$ and $\mathrm{H}_{2}$ from Photocatalytic Reforming of Glucose Aqueous Solution on Sulfated $\mathrm{Pd}-\mathrm{TiO}_{2}$ Catalysts
}

\author{
Vincenzo Vaiano', Giuseppina lervolino', Giuseppe Sarno', Diana Sannino ${ }^{1 *}$, Luigi Rizzo², \\ Julie J. Murcia Mesa ${ }^{3,4}$, Maria C. Hidalgo ${ }^{4}$ and Jose A. Navío ${ }^{4}$ \\ ${ }^{1}$ Department of Industrial Engineering, University of Salerno, via Giovanni Paolo II, 132, 84084 Fisciano (SA) - Italy \\ 2 Department of Civil Engineering, University of Salerno, via Giovanni Paolo II, 132, 84084 Fisciano (SA) - Italy \\ ${ }^{3}$ Universidad Pedagógica y Tecnológica de Colombia, Avenida Central del Norte, Tunja, Boyacá - Colombia \\ ${ }^{4}$ Instituto de Ciencia de Materiales de Sevilla (ICMS), Consejo Superior de Investigaciones Científicas (CSIC), Universidad de Sevilla, \\ Américo Vespucio 49, 41092 Sevilla - Spain \\ e-mail: dsannino@unisa.it \\ * Corresponding author
}

\begin{abstract}
In this work, the simultaneous production of $\mathrm{CH}_{4}$ and $\mathrm{H}_{2}$ from photocatalytic reforming of glucose aqueous solution on Pd-TiO $\mathrm{O}_{2}$ catalysts under UV light irradiation by Light-Emitting Diodes (LED) was investigated. The Pd-TiO $\mathrm{O}_{2}$ catalysts were prepared by the photodeposition method. The Pd content was in the range 0.5-2 wt\% and a photodeposition time in the range 15-120 min was used. $\mathrm{Pd}-\mathrm{TiO}_{2}$ powders were extensively characterized by X-Ray Diffraction (XRD), $S_{B E T}, X$-Ray Fluorescence spectrometry (XRF), UV-Vis Diffuse Reflectance Spectra (UV-Vis DRS), TEM and $X$-Ray Photoelectron Spectroscopy (XPS). It was found that the lower Pd loading (0.5 wt\%) and $120 \mathrm{~min}$ of photodeposition time allowed us to obtain homogeneously distributed metal nanoparticles of small size; it was also observed that the increase in the metal loading and deposition time led to increasing the $\mathrm{Pd}^{0}$ species effectively deposited on the sulfated $\mathrm{TiO}_{2}$ surface. Particle size and the oxidation state of the palladium were the main factors influencing the photocatalytic activity and selectivity. The presence of palladium on the sulfated titania surface enhanced the $\mathrm{H}_{2}$ and $\mathrm{CH}_{4}$ production. In fact, on the catalyst with $0.5 \mathrm{wt} \%$ Pd loading and $120 \mathrm{~min}$ of photodeposition time, $\mathrm{H}_{2}$ production of about $26 \mu \mathrm{mol}$ was obtained after $3 \mathrm{~h}$ of irradiation time, higher than that obtained with titania without Pd (about $8.5 \mu$ mol). The same result was obtained for the methane production. The initial $\mathrm{pH}$ of the solution strongly affected the selectivity of the system. In more acidic conditions, the production of $\mathrm{H}_{2}$ was enhanced, while the $\mathrm{CH}_{4}$ formation was higher under alkaline conditions.
\end{abstract}

Résumé - Production simultanée de $\mathrm{CH}_{4}$ et $\mathrm{H}_{2}$ par réformage photocatalytique d'une solution aqueuse de glucose sur un catalyseur ${\mathrm{Pd}-\mathrm{TiO}_{2}}_{2}$ sulfaté - Dans cette recherche, la production simultanée de $\mathrm{CH}_{4}$ et $\mathrm{H}_{2}$ par le reformage photocatalytique de glucose sur les catalyseurs $\mathrm{Pd}_{-} \mathrm{TiO}_{2}$ sous irradiation de lumière UV réalisée par des diodes électroluminescentes (LED) a été étudiée. Les échantillons de $\mathrm{Pd}-\mathrm{TiO}_{2}$ ont été préparés par la méthode de photodéposition. Le contenu de Pd était compris entre $0,5-2 \%$ en poids et il a été utilisé un temps de photodéposition dans la gamme 15-20 minutes. Les poudres $\mathrm{Pd}-\mathrm{TiO}_{2}$ ont été caractérisées par diffraction des rayons X (XRD), surface spécifique BET $\left(\mathrm{S}_{\mathrm{BET}}\right)$, fluorescence $\mathrm{X}(\mathrm{XRF})$, spectrométrie UV visible (UV vis DRS), microscopie 
électronique à transmission (TEM) et spectrométrie photo électronique X (XPS). Il a été constaté que le chargement inférieur de $\mathrm{Pd}(0,5 \%$ en poids) et 120 minutes de temps de photodéposition conduit à une répartition homogène des nanoparticules métalliques avec une faible dimension ; il a aussi été observé que l'augmentation de la charge de métal et celle de durée du dépôt conduisent à augmenter les espèces de $\mathrm{Pd}^{0}$ efficacement déposées sur la surface de $\mathrm{TiO}_{2}$. La taille des particules et l'état d'oxydation du palladium ont été les principaux facteurs qui influent sur l'activité photocatalytique et sur la sélectivité. La présence de palladium sur la surface de l'oxyde de titane accroit la production de $\mathrm{H}_{2}$ et $\mathrm{CH}_{4}$. En fait, sur le catalyseur avec $0,5 \%$ en poids du chargement de Pd et 120 min de temps de photodéposition, il a été obtenu une production de $\mathrm{H}_{2}$ d'environ $26 \mu \mathrm{mol}$ après 3 heures de temps d'irradiation, quantité supérieure à celle obtenue avec $\mathrm{TiO}_{2}$ sans $\mathrm{Pd}$ (environ 8,5 $\mu \mathrm{mol}$ ). Le même résultat a été obtenu pour la production de méthane. Le $\mathrm{pH}$ initial de la solution a fortement influencé la sélectivité du système. Dans des conditions plus acides, la production de $\mathrm{H}_{2}$ a été améliorée, tandis que la formation de $\mathrm{CH}_{4}$ a été plus élevée pour des conditions alcalines.

\section{INTRODUCTION}

In recent years, there have been intensive efforts toward the development of novel technologies for the production of hydrogen or methane from renewable resources, mainly water and biomass [1-3]. In particular, the food industry produces a large amount of solid and liquid wastes which could be valorized. In wastewater from the food industry, it is possible to find a high concentration of glucose. Glucose can be converted into hydrogen by several reactions, such as steam reforming [4, 5], wet oxidation of glucose [6], oxidative glucose reforming [7], pyrolysis [8], biophotolysis [9, 10], dark fermentation [11], electrolysis [12] and photocatalysis [13, 14]. Hydrogen has been identified as an ideal energy carrier for sustainable energy development [15-18] and it can be used in a fuel cell to generate electricity with high efficiency. In order to support a sustainable hydrogen economy, it is crucial to produce hydrogen cleanly and renewably. Typically, heterogeneous photocatalysis is studied with the aim of removing organic pollutants from wastewater $[19,20]$ through oxidation reactions which can finally result in the production of $\mathrm{CO}_{2}$ and water. An interesting approach is to explore, in parallel to wastewater treatment, opportunities of mass recovery which can be sold as secondary raw material or used as energy resources, such as hydrogen and methane. Some wastewaters from food processes contain a high concentration of sugars, particularly glucose, which should be removed before effluent disposal or reuse, but if properly treated, hydrogen could be produced. In the past two decades, photocatalytic processes have been investigated as a possible method to obtain hydrogen glucose aqueous solutions [21]. The photocatalytic hydrogen production by decomposition of water containing glucose seems to have become a very powerful method for the practical and lowcost technologies in the hydrogen based energy system $[22,23]$. Different catalysts containing noble metals on the surface $(\mathrm{Au}, \mathrm{Pt}, \mathrm{Pd})$ or nanostructured $\mathrm{Fe}_{2} \mathrm{O}_{3}$ polymorphs
[24] have been investigated $[22,25]$ because the presence of noble metals on the surface of the semiconductor improves photocatalytic performances. Linsebigler et al. (1995) [26] observed that by adding a small amount of noble metals, it is possible to suppress to some extent the charge recombination by forming a Schottky barrier. Rh or Pt, Pd, $\mathrm{Cu}$ or $\mathrm{Ni}$ supported on $\mathrm{TiO}_{2}$ have been investigated in the conversion of glucose into $\mathrm{H}_{2}$ [27]. However, the reactor configurations reported in the literature only include the use of mercury vapor lamps with high voltage as a light source $(125-400 \mathrm{~W})[28,29]$. Moreover, a few results are reported in the scientific literature about the production of methane through photocatalytic reforming of wastewater. Generally, the production of methane derives from processes such as anaerobic digestion [30,31]. The production of hydrogen or methane from ethanol by photocatalytic reaction has also been reported [32].

In this work, the simultaneous production of $\mathrm{CH}_{4}$ and $\mathrm{H}_{2}$ from photocatalytic reforming of glucose on $\mathrm{Pd}_{-}-\mathrm{TiO}_{2}$ was investigated under UV light irradiation by Light-Emitting Diodes (LED) with low energy consumption $(10 \mathrm{~W})$. $\mathrm{TiO}_{2}$ was prepared via a sol-gel technique, while Pd addition was carried out by photodeposition. The influence of some parameters, such as: photodeposition time and Pd loading on the final properties of the materials and their photocatalytic efficiency for glucose reforming was evaluated. The effect of the photocatalyst dosage and initial $\mathrm{pH}$ on photocatalytic performance was also investigated.

\section{EXPERIMENTAL}

\subsection{Synthesis of Photocatalysts}

$\mathrm{TiO}_{2}$ was prepared by hydrolysis of titanium tetraisopropoxide (Aldrich, 97\%) in isopropanol solution (1.6M) by the slow addition of distilled water (volume ratio 
isopropanol/water 1:1). The $\mathrm{TiO}_{2}$ powder was recovered by filtration, dried at $110^{\circ} \mathrm{C}$ for $24 \mathrm{~h}$ and pre-treated by immersion in a $1 \mathrm{M}$ sulfuric acid solution under continuous stirring for $1 \mathrm{~h}$. After pre-treatment, the solution was filtered, dried and calcinated at $650^{\circ} \mathrm{C}$ for $2 \mathrm{~h}$; the resulting photocatalyst was used as starting material $\left(\mathrm{S}-\mathrm{TiO}_{2}\right)$. The fresh $\mathrm{TiO}_{2}$ powder was submitted to a sulfate treatment, taking into account that previous results have shown that sulfate pre-treatment stabilizes the anatase phase up to high temperatures and protects the surface area against sintering [33-36].

Photodeposition of palladium was performed over the sulfated $\mathrm{TiO}_{2}$ powders using palladium chloride (II) $\left(\mathrm{PdCl}_{2}\right.$, Aldrich $99 \%$ ) as the metal precursor. Under an inert atmosphere $\left(\mathrm{N}_{2}\right)$, a suspension of the corresponding $\mathrm{TiO}_{2}$ sample in distilled water containing isopropanol (Merck 99.8\%), which acts as the sacrificial donor, was prepared. Then, the appropriate amount of $\mathrm{PdCl}_{2}$ solution to obtain the desired nominal palladium loading was added; in order to dissolve the metal precursor, the $\mathrm{pH}$ of this solution was adjusted to 2 by using a $\mathrm{HCl} 0.1 \mathrm{M}$ solution. Photodeposition of palladium was then performed by illuminating the suspension for 120 min with an Osram Ultra-Vitalux lamp (300 W) which possesses a sun-like radiation spectrum with a main emission line in the UVA range at $365 \mathrm{~nm}$. The light intensity on the suspensions was $60 \mathrm{~W} / \mathrm{m}^{2}$ determined by a PMA 2200 UVA photometer (Solar Light Co.). After photodeposition, the powders were recovered by filtration and dried at $110^{\circ} \mathrm{C}$ overnight. Series of $\mathrm{Pd}-\mathrm{TiO}_{2}$ catalysts were prepared by using different metal contents $\left(0.5 \%\right.$ or $2 \%$ weight total to $\left.\mathrm{TiO}_{2}\right)$ and photodeposition times ( 15 or $120 \mathrm{~min}$ ). The photocatalysts prepared by $\mathrm{TiO}_{2}$ metallization will be denoted in this document as 0.5Pd15, 0.5Pd120, $2 \mathrm{Pd} 15$ and $2 \mathrm{Pd} 120$.

\subsection{Photocatalyst Characterization}

All the materials were widely characterized using different techniques. The crystalline phase composition and degree of crystallinity of the samples were estimated by XRD. XRD patterns were obtained on a Siemens D-501 diffractometer with a Ni filter and graphite monochromator using $\mathrm{Cu} \mathrm{K} \alpha$ radiation. Anatase crystallite sizes were calculated from the line broadening of the main anatase XRD peak (101) by using the Scherrer equation. Peaks were fitted by using a Voigt function.

Specific surface area $\left(\mathrm{S}_{\mathrm{BET}}\right)$ measurements were carried out using low-temperature nitrogen adsorption in a Micromeritics ASAP 2010 instrument. Degasification of the samples was performed at $150^{\circ} \mathrm{C}$.

The chemical composition and total palladium content in the samples were determined by XRF in a PANalytical Axios sequential spectrophotometer equipped with a rhodium tube as the source of radiation. XRF measurements were performed on pressed pellets (sample included in $10 \mathrm{wt} \%$ of wax).
The light absorption properties of the samples were studied by UV-Vis spectroscopy. The UV-Vis DRS were recorded on a Varian spectrometer (model Cary 100) equipped with an integrating sphere and using $\mathrm{BaSO}_{4}$ as a reference. Band-gap values were calculated from the corresponding Kubelka-Munk functions, $F(R \infty)$, which are proportional to the absorption of radiation by plotting $(\mathrm{F}(\mathrm{R} \infty) \cdot \mathrm{h} v)^{1 / 2}$ against $\mathrm{h} v$.

Palladium particle sizes were evaluated by TEM, in a Philips CM 200 microscope. The samples were dispersed in ethanol using an ultrasonicator and dropped on a carbon grid.

XPS studies were carried out on a Leybold-Heraeus LHS-10 spectrometer, working with a constant pass energy of $50 \mathrm{eV}$. The spectrometer's main chamber, working at a pressure $<2 \times 10^{-9}$ Torr, is equipped with an EA-200 MCD hemispherical electron analyzer with a dual X-ray source working with $\mathrm{Al} \mathrm{K \alpha}(h v=1486.6 \mathrm{eV})$ at 120 wand $30 \mathrm{~mA}$. The $\mathrm{C} 1 \mathrm{~s}$ signal $(284.6 \mathrm{eV})$ was used as an internal energy reference in all the experiments. Samples were outgassed in the prechamber of the instrument at $150^{\circ} \mathrm{C}$ up to a pressure $<2 \times 10^{-8}$ Torr to remove chemisorbed water.

\subsection{Photocatalytic Tests}

Photocatalytic experiments were carried out with a Pyrex cylindrical reactor $(\mathrm{ID}=2.5 \mathrm{~cm})$ equipped with a $\mathrm{N}_{2}$ distributor device $(Q=0.122 \mathrm{NL} / \mathrm{min})$. The continuous mixing of the glucose solution and the photocatalyst was carried out by external recirculation of water through the use of a peristaltic pump. A thermocouple was inserted inside the reactor to monitor the temperature during irradiation. The photoreactor was irradiated by a strip composed of 15 UV-LED (nominal power: $10 \mathrm{~W}$ ) with wavelength emission in the range 375-380 nm. The LED strip was positioned around the external surface of the reactor so that the light source uniformly irradiated the reaction volume (light intensity: $1.5 \mathrm{~W} / \mathrm{m}^{2}$ ). Typically, $0.04 \mathrm{~g}$ of catalyst was suspended in an $80-\mathrm{mL}$ aqueous solution containing $500 \mathrm{mg} / \mathrm{L}$ of glucose $\left(\mathrm{D}^{+}\right.$Glucose VWR, Sigma-Aldrich). The suspension was left in dark conditions for 2 hours to reach the adsorption-desorption equilibrium of glucose on the photocatalysts' surface, and then a photocatalytic reaction was initiated under UV light for up to 3 hours. Hydrogen and methane yield during the irradiation time is evaluated according to the following relationship:

$$
\begin{aligned}
R_{\mathrm{H}_{2}} & =\frac{2 \cdot n_{\mathrm{H}_{2}}}{12 \cdot n_{\mathrm{C}_{6} \mathrm{H}_{12} \mathrm{O}_{6}}^{0}} \cdot 100 \\
R_{\mathrm{CH}_{4}} & =\frac{4 \cdot n_{\mathrm{CH}_{4}}}{12 \cdot n_{\mathrm{C}_{6} \mathrm{H}_{12} \mathrm{O}_{6}}^{0}} \cdot 100
\end{aligned}
$$

where: $R=$ yield; $n_{\mathrm{H}_{2}}=$ moles of $\mathrm{H}_{2}$ produced; $n_{\mathrm{CH}_{4}}=$ moles of $\mathrm{CH}_{4}$ produced; $n_{\mathrm{C}_{6} \mathrm{H}_{12} \mathrm{O}_{6}}^{0}=$ moles of glucose after dark adsorption. 
To evaluate the influence of the initial $\mathrm{pH}$ on the production of $\mathrm{H}_{2}$ and $\mathrm{CH}_{4}$, the $\mathrm{pH}$ of the solution was changed by adding nitric acid (Baker Analyzed, 65\%) or ammonium hydroxide (Baker Analyzed, 30\%). About $2 \mathrm{~mL}$ of samples were taken from the photoreactor at different times and filtered in order to remove $\mathrm{Pd}-\mathrm{TiO}_{2}$ particles before analysis.

\subsection{Chemical Analysis}

The analysis of the gaseous phase from the photoreactor was performed by online gas chromatography (MicroGC, Agilent) with a TDX-01 column for the analysis of $\mathrm{CO}, \mathrm{CO}_{2}$, $\mathrm{CH}_{4}$ and $\mathrm{H}_{2}$ and equipped with a molecular sieve for the analysis of oxygen. The concentration of glucose was measured by a spectrophotometric method [37, 38]. Briefly, a $2-\mathrm{mL}$ aliquot of a carbohydrate solution is mixed with $1 \mathrm{~mL}$ of $5 \mathrm{wt} \%$ aqueous solution of phenol (Sigma-Aldrich) in a test tube. Subsequently, $5 \mathrm{~mL}$ of concentrated sulfuric acid (Sigma-Aldrich) is added rapidly to the mixture. Then, light absorption at $490 \mathrm{~nm}$ is recorded on a UV-Vis spectrophotometer (Perkin Elmer).

\section{RESULTS AND DISCUSSION}

\subsection{Photocatalyst Characterization}

\subsubsection{X-Ray Diffraction}

Figure 1 shows the XRD patterns of the $\mathrm{Pd}-\mathrm{TiO}_{2}$ photocatalysts; the only crystalline phase present in all the samples was anatase, identified by the main XRD peak located at $25.25^{\circ}$, thus indicating that the sulfation pre-treatment inhibited the formation of the rutile phase of $\mathrm{TiO}_{2}$ during the calcination process, as has been reported by different authors [33-36].

On the other hand, photodeposition of palladium did not affect the phase composition in any case. In the spectra of metallized samples, a diffraction peak for Pd was detected at $40^{\circ}$; this peak is assigned to $\mathrm{Pd}$ (111) [39]. It was observed that the intensity of this peak increased with the Pd loading,

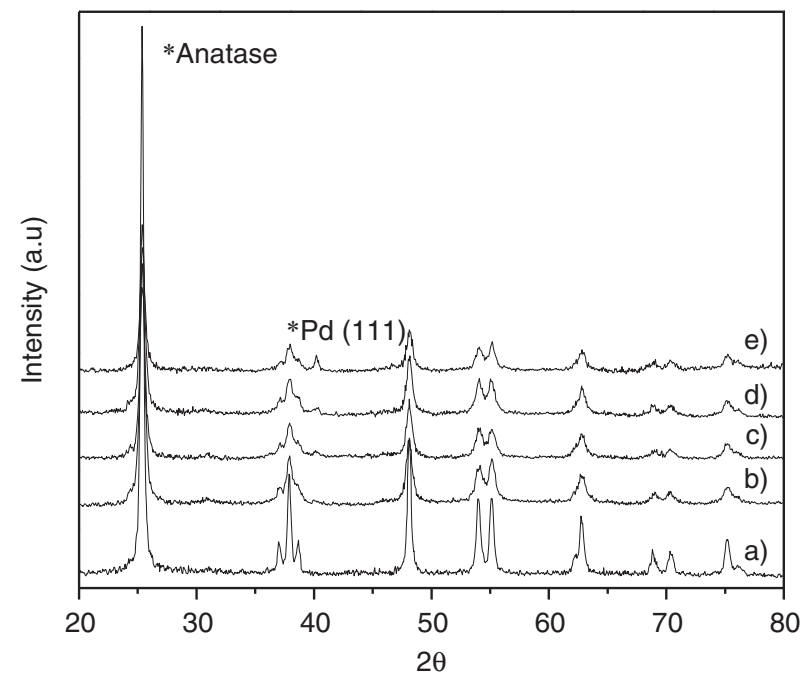

Figure 1

XRD patterns for $\mathrm{TiO}_{2}$ and $\mathrm{Pd}-\mathrm{TiO}_{2}$ photocatalysts prepared with different $\mathrm{Pd}$ contents and deposition times. a) $\mathrm{TiO}_{2}$; b) $0.5 \mathrm{wt} \% \mathrm{Pd}-\mathrm{TiO}_{2}, 15 \mathrm{~min}$; c) $0.5 \mathrm{wt} \% \mathrm{Pd}-\mathrm{TiO}_{2}, 120 \mathrm{~min}$; d) $2 \mathrm{wt} \% \mathrm{Pd}-\mathrm{TiO}_{2}, 15 \mathrm{~min}$; e) $2 \mathrm{wt} \% \mathrm{Pd}-\mathrm{TiO}_{2}, 120 \mathrm{~min}$.

being highest in the catalysts prepared with $2 \mathrm{wt} \%$ of nominal content and $120 \mathrm{~min}$ of deposition time; this could be due to a higher metal particle size in these samples.

The anatase crystallite sizes calculated by the Scherrer equation from the (101) peak of the XRD pattern are listed in Table 1 . As can be seen, the $\mathrm{TiO}_{2}$ presents a value of $20 \mathrm{~nm}$; the Pd addition did not significantly modify crystallite sizes beyond this value.

\subsubsection{BET Surface Area}

BET surface area values $\left(\mathrm{S}_{\mathrm{BET}}\right)$ for all the samples are shown in Table 1. As can be seen, Pd addition did not induce significant modifications in the $\mathrm{S}_{\mathrm{BET}}$ of the analyzed materials, and the observed slight decreases are probably due to pore blocking by metal deposits on the $\mathrm{TiO}_{2}$ surface.

TABLE 1

Characterization of the investigated photocatalysts

\begin{tabular}{|c|c|c|c|c|c|c|}
\hline Photocatalyst & $\begin{array}{c}\text { Pd nominal } \\
\text { loading (wt } \%)\end{array}$ & $\begin{array}{l}\text { Photodeposition } \\
\text { time (min) }\end{array}$ & $\begin{array}{l}\text { Real Pd content } \\
\quad(w t \%)^{*}\end{array}$ & $\begin{array}{l}\text { Sulfate amount } \\
(\mathrm{wt} \%)\end{array}$ & $\mathrm{S}_{\mathrm{BET}}\left(\mathrm{m}^{2} / \mathrm{g}\right)$ & Band gap (ev) ${ }^{* *}$ \\
\hline $\mathrm{S}-\mathrm{TiO}_{2}$ & 0 & - & - & 0.30 & 58 & 3.2 \\
\hline $0.5 \mathrm{Pd} 15$ & 0.5 & 15 & 0.18 & 0.28 & 46 & 3.2 \\
\hline $0.5 \mathrm{Pd} 120$ & 0.5 & 120 & 0.20 & 0.27 & 48 & 3.2 \\
\hline $2 \mathrm{Pd} 15$ & 2 & 15 & 0.34 & 0.28 & 48 & 3.2 \\
\hline $2 \mathrm{Pd} 120$ & 2 & 120 & 0.80 & 0.28 & 49 & 3.2 \\
\hline
\end{tabular}




\subsubsection{X-Ray Fluorescence}

The real palladium content in the metallized samples was measured by XRF and the values are listed in Table 1 . These values are less than the nominal metal content used to prepare these materials $(0.5$ or $2 \mathrm{wt} \%)$, indicating an incomplete reduction of the metal precursor $\left(\mathrm{PdCl}_{2}\right)$ on the $\mathrm{TiO}_{2}$ surface during the photodeposition process. However, the amount of deposited Pd was highest in the samples prepared with the highest deposition time (120 $\mathrm{min})$.

In all the samples, XRF analysis revealed that a certain amount of $\mathrm{S}$ and $\mathrm{Cl}^{-}$species remained on the solid after preparation. The sulfur content was between 0.27 and $0.30 \%$, and the chloride content was below $0.02 \%$.

\subsubsection{UV-Vis Diffuse Reflectance Spectra}

The absorption spectra of all the samples are shown in Figure 2. The typical absorption band edge of the $\mathrm{TiO}_{2}$ semiconductor was observed at around $400 \mathrm{~nm}$ for all the samples. As can be seen, metallization did not substantially alter the absorption properties of the samples; however, a slight increase in absorption throughout the visible range of the spectrum was observed due to the gray color of these materials; this increase is more evident in samples with the highest Pd loading.

From the UV-Vis DRS spectra, band-gap energies were calculated, being $3.20 \mathrm{eV}$ for the $\mathrm{TiO}_{2}$ corresponding to the anatase phase. Pd photodeposition did not induce any significant change in this value; estimated band-gap energies are between 3.2 and $3.3 \mathrm{eV}$.

\subsubsection{Microscopic Analysis}

The morphology and Pd particle size in the samples prepared was studied by TEM.

As was observed from the TEM images, in the samples prepared with $0.5 \mathrm{wt} \% \mathrm{Pd}$ loading, metal nanoparticles appear to be homogenously distributed all over the surface, with sizes around 2-4 $\mathrm{nm}$ (images are not shown).

Figure 3 shows representative TEM images of $\mathrm{TiO}_{2}$ after photodeposition of $2 \mathrm{wt} \%$ Pd with irradiation times of 15 and $120 \mathrm{~min}$ (Fig. 3a and 3b, respectively). In both samples, palladium particles can be seen as dark spherical spots placed on the larger anatase particles; in these samples Pd nanoparticles are heterogeneously distributed on the $\mathrm{TiO}_{2}$ surface and particle sizes higher than $6 \mathrm{~nm}$ were observed.

\subsubsection{XPS Analyses}

XPS measurements were performed and a summary of these results is reported in Table 1.

Figure 4 shows spectra of Ti $2 p$ and $O 1$ s for the different samples analyzed. The Ti $2 p$ core peaks exhibit a main component at around $458.5 \pm 0.1 \mathrm{eV}\left(\mathrm{Ti} 2 \mathrm{p}_{3 / 2}\right)$ in all the samples, representative of the $\mathrm{Ti}^{4+}$ ions in the $\mathrm{TiO}_{2}$ lattice. The addition of Pd did not modify the oxidation state or the chemical environment of titanium atoms at the surface of the $\mathrm{TiO}_{2}$. In the $\mathrm{O} 1 \mathrm{~s}$ region, a peak located at $529.8 \pm 0.2 \mathrm{eV}$ can be observed for all the samples, assigned to oxygen atoms in the $\mathrm{TiO}_{2}$ lattice. This peak is asymmetric, with a shoulder at higher binding energies assigned to surface $\mathrm{OH}$ groups. The shoulder is more prominent in the non-metallized $\mathrm{TiO}_{2}$ sample, indicating a higher hydroxylation degree in

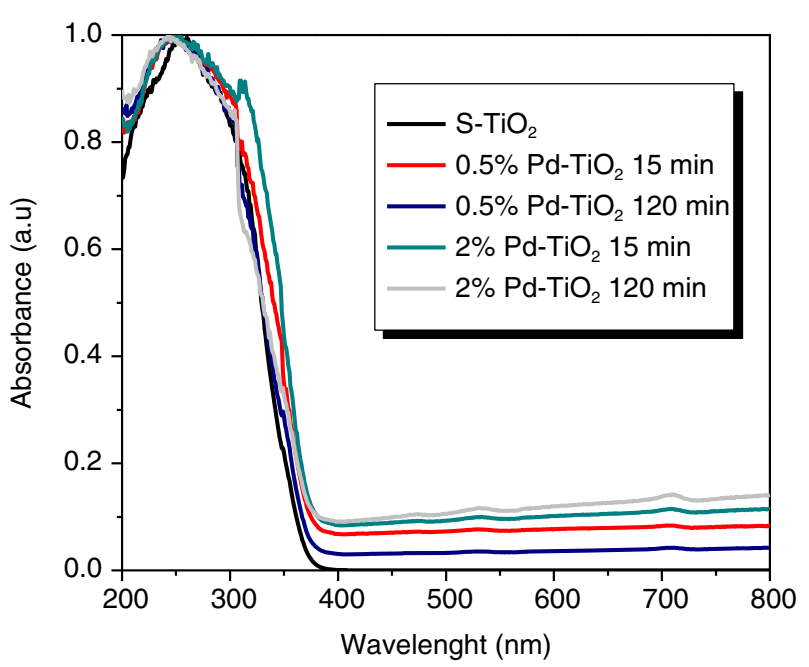

Figure 2

UV-Vis DRS spectra for the investigated photocatalysts.

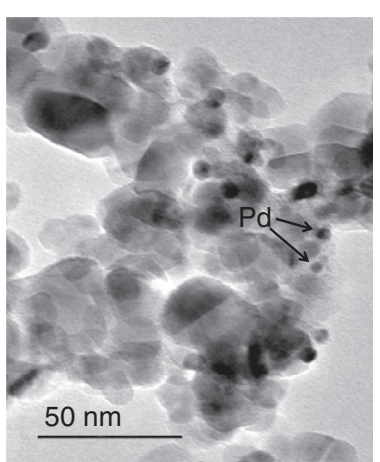

a)

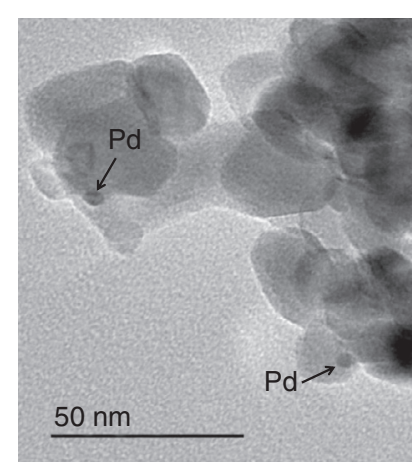

b)
Figure 3

TEM images of $2 \mathrm{wt} \%$ Pd-TiO ${ }_{2}$ samples. a) $\mathrm{Pd}-\mathrm{TiO}_{2}, 15 \mathrm{~min}$; b) $\mathrm{Pd}-\mathrm{TiO}_{2}, 120 \mathrm{~min}$. 

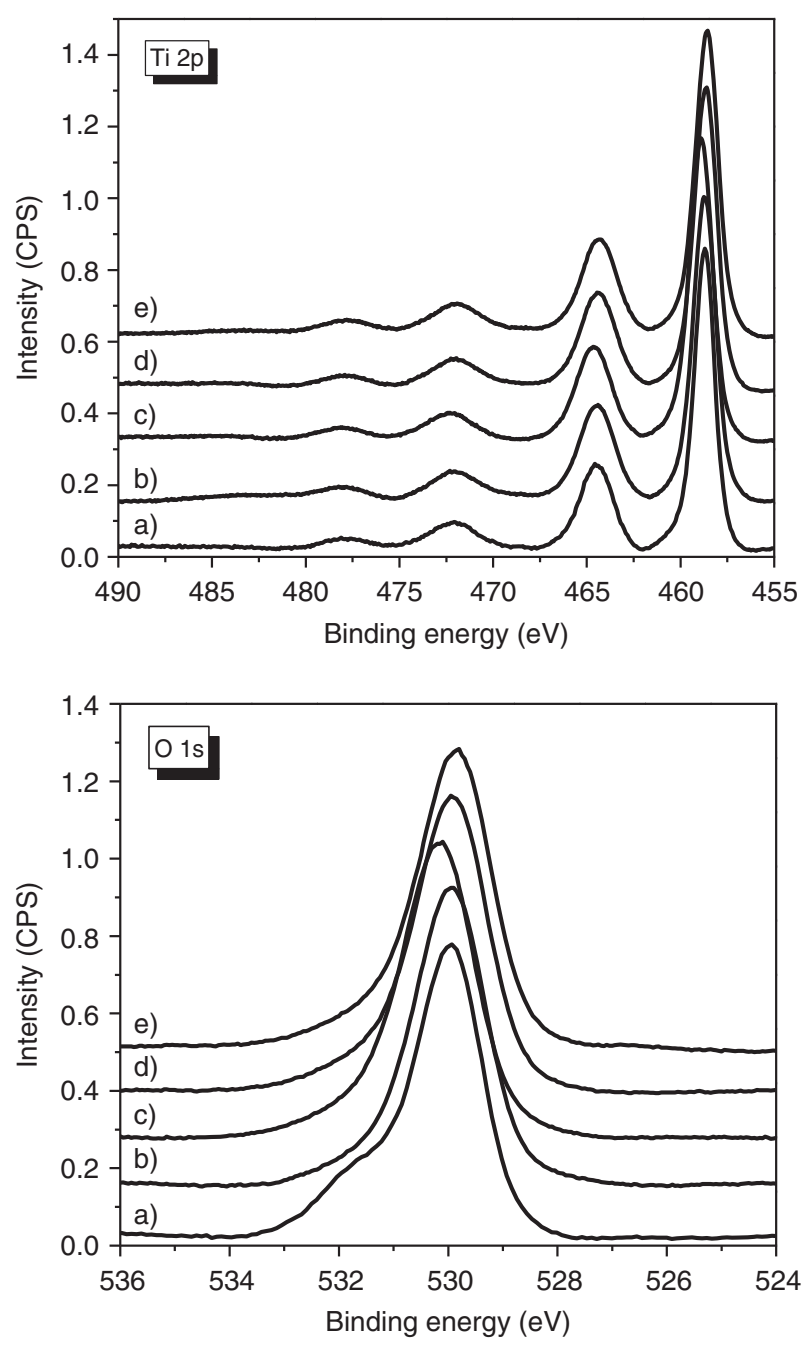

Figure 4

XPS core level spectra of Ti $2 \mathrm{p}$ and $\mathrm{O} 1 \mathrm{~s}$ regions for the investigated photocatalysts. a) $\mathrm{S}-\mathrm{TiO}_{2}$; b) $0.5 \mathrm{wt} \% \mathrm{Pd}_{-} \mathrm{TiO}_{2}, 15 \mathrm{~min}$; c) $0.5 \mathrm{wt} \% \mathrm{Pd}-\mathrm{TiO}_{2}, 120 \mathrm{~min}$; d) $2 \mathrm{wt} \% \mathrm{Pd}-\mathrm{TiO}_{2}, 15 \mathrm{~min}$; e) $2 \mathrm{wt} \% \mathrm{Pd}-\mathrm{TiO}_{2}, 15 \mathrm{~min}$.

this sample. The intensity of this shoulder is lower in $\mathrm{Pd}-\mathrm{TiO}_{2}$ samples; this is mainly due to the presence of metallic nanoparticles partially covering the $\mathrm{TiO}_{2}$ surface, as was observed by TEM (Fig. 3).

The study of XPS Pd 3d peak regions can provide information concerning the oxidation state of the Pd species adsorbed on the $\mathrm{TiO}_{2}$ surface. A Pd $3 \mathrm{~d}$ region is formed by a doublet corresponding to the signals for $3 \mathrm{~d}_{7 / 2}$ and $3 d_{5 / 2}$. The $P d 3 d_{7 / 2}$ binding energy for metallic palladium $\left(\mathrm{Pd}^{0}\right)$ appears near to $334 \mathrm{eV}$, while for partially oxidized forms $\left(\mathrm{Pd}^{2+} / \mathrm{Pd}^{4+}\right)$ it appears at higher binding energies with values of ca. 336 and $338 \mathrm{eV}$, respectively [40]. The XPS Pd $3 \mathrm{~d}$ region for the $\mathrm{Pd}-\mathrm{TiO}_{2}$ samples prepared with 0.5 and

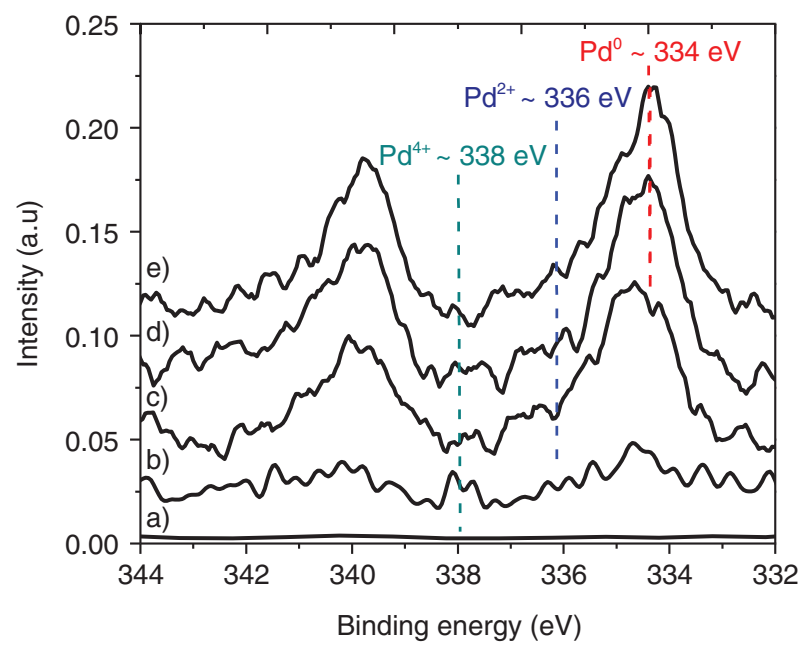

Figure 5

Comparative XPS spectra of Pd $3 d_{7 / 2}$ and $3 d_{7 / 2}$ core levels of $\mathrm{Pd}-\mathrm{TiO}_{2}$ catalysts prepared with different $\mathrm{Pd}$ contents and deposition times. a) $\mathrm{S}^{-\mathrm{TiO}_{2}}$; b) $0.5 \mathrm{wt} \% \mathrm{Pd}^{-\mathrm{TiO}_{2}}, 15 \mathrm{~min}$; c) $0.5 \mathrm{wt} \%$ $\mathrm{Pd}-\mathrm{TiO}_{2}, 120 \mathrm{~min}$; d) $2 \mathrm{wt} \% \mathrm{Pd}-\mathrm{TiO}_{2}, 15 \mathrm{~min}$; e) $2 \mathrm{wt} \%$ $\mathrm{Pd}-\mathrm{TiO}_{2}, 120 \mathrm{~min}$.

$2 \mathrm{wt} \%$ metal content and deposition times of 15 and $120 \mathrm{~min}$ is shown in Figure 5. All the spectra were calibrated with the $\mathrm{C} 1 \mathrm{~s}$ peak at $284.6 \mathrm{eV}$ attributed to "adventitious" surface carbon. $\mathrm{Pd}^{0}$ and $\mathrm{Pd}^{\sigma+}$ species were detected in all the analyzed samples, thus indicating an incomplete reduction of the metal precursor on the $\mathrm{TiO}_{2}$ surface; these observations are in agreement with the results obtained by XRF analysis (Sect. 2.1.3). However, the $\mathrm{Pd}^{0}$ on $\mathrm{TiO}_{2}$ increased with the deposition time and with the metal content. As can be seen qualitatively in Figure 5, the highest intensity of the peaks assigned to $\mathrm{Pd}^{0}$ species content was observed in the catalyst prepared with $120 \mathrm{~min}$ of deposition time and $2 \mathrm{wt} \%$ of nominal Pd loading.

$\operatorname{Pd} 3 \mathrm{~d}_{7 / 2}$ and $3 \mathrm{~d}_{5 / 2}$ doublets were deconvoluted using the UNIFIT 2009 software assuming a doublet separation of $5.2 \mathrm{eV}$ of the two components. The spectrum obtained for the $2 \mathrm{wt} \% \mathrm{Pd}-\mathrm{TiO}_{2}$ catalysts prepared with $120 \mathrm{~min}$ of deposition time is shown in Figure 6. A Shirley-type background was subtracted from each spectrum. By the deconvolution of the doublets, it is possible to observe clearly the presence of $\mathrm{Pd}^{0} / \mathrm{Pd}^{\sigma+}$ species in the analyzed sample.

\subsection{Photocatalytic Results}

\subsubsection{Influence of Photocatalyst Formulation}

The preliminary test performed in dark conditions showed no reaction product in the gaseous phase. 


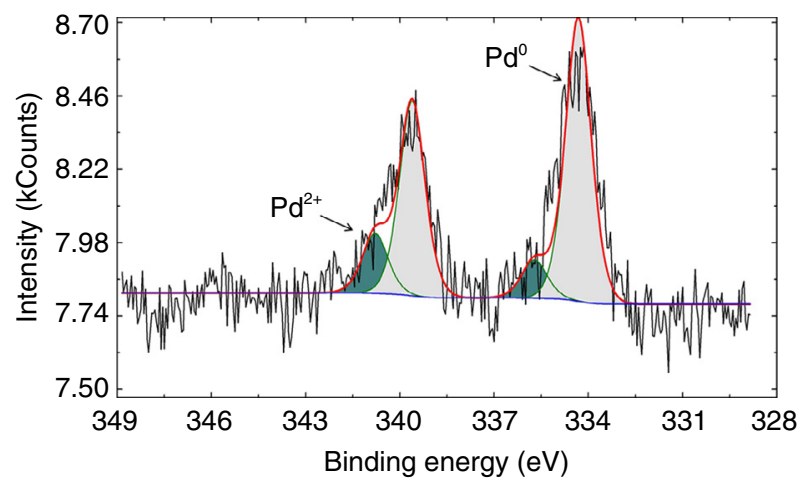

Figure 6

XPS Pd $3 d_{7 / 2}$ and $3 d_{7 / 2}$ regions for the $2 \mathrm{wt} \% \mathrm{Pd}-\mathrm{TiO}_{2}$ catalyst prepared with $120 \mathrm{~min}$ of deposition time.

The final concentration of glucose after the dark period was 351 and $305 \mathrm{mg} / \mathrm{L}$ for $\mathrm{S}_{-} \mathrm{TiO}_{2}$ and $0.5 \mathrm{Pd} 120$, respectively.

Control tests with UV as a standalone process and under photocatalytic conditions with $\mathrm{UV} / \mathrm{S}-\mathrm{TiO}_{2}$ and $\mathrm{UV} / 0.5 \mathrm{Pd} 120$ were carried out to evaluate the contribution of each process in the production of hydrogen and methane from glucose (Fig. 7). During the irradiation time, the production of $\mathrm{H}_{2}, \mathrm{CO}_{2}$ and $\mathrm{CH}_{4}$ was observed, but no formation of $\mathrm{CO}$ and $\mathrm{O}_{2}$ was observed. The presence of palladium photodeposited on the surface of the titania enhanced the production of hydrogen (Fig. 7a). In particular, a production of $\mathrm{H}_{2}$ as high as $26 \mu \mathrm{mol}\left(R_{\mathrm{H}_{2}}=3 \%\right)$ after 3 hours of irradiation with a $0.5 \mathrm{Pd} 120$ catalyst was observed. The hydrogen yield on $0.5 \mathrm{Pd} 120(3 \%)$ is significantly higher than that obtained on $\mathrm{S}_{-} \mathrm{TiO}_{2}(0.9 \%)$. However, a large fraction of glucose is not converted into hydrogen and methane under the present conditions.

These results are in agreement with those reported in the literature. In particular, loading noble metals such as Pt [41] and $\mathrm{Au}$ [42] onto the photocatalyst surface can separate photogenerated electrons and holes more effectively and thus improve hydrogen production. In a similar way, the coexistence of $\mathrm{Pd}$ with $\mathrm{TiO}_{2}$ in the $\mathrm{Pd}-\mathrm{TiO}_{2}$ composite photocatalyst may lower the recombination rate between photogenerated electrons and holes, thus improving the efficiency of the photocatalysis process. It is well known that there are two forms of electron-hole recombination in $\mathrm{TiO}_{2}$, surface recombination and bulk recombination, and both can lower the efficiency of photocatalysis [43]. The Fermi energy level of $\mathrm{Pd}$ is lower than that of $\mathrm{TiO}_{2}$, and since they are closer to each other, the electrons on the surface of $\mathrm{TiO}_{2}$ can spontaneously transfer to the surface of Pd until their Fermi energy levels become equal. As a result, excessive negative charges
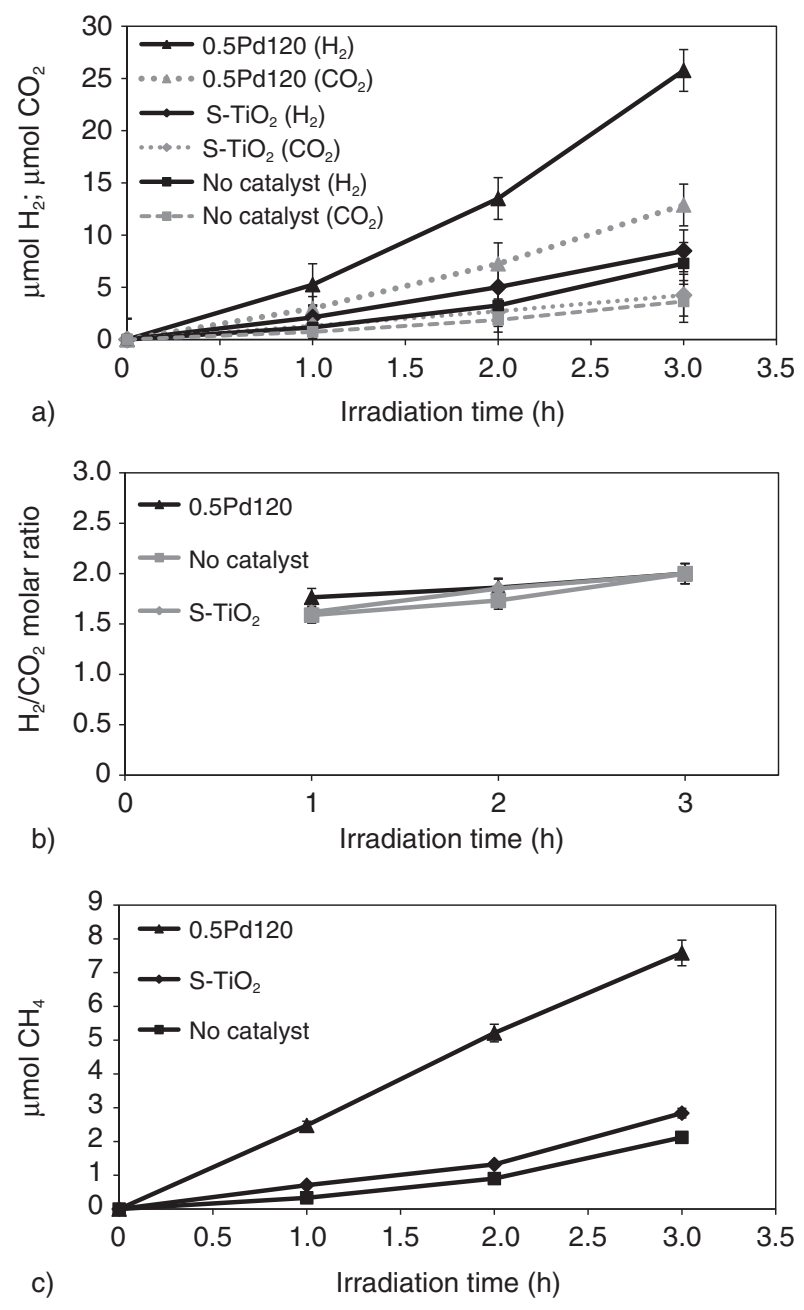

Figure 7

Control tests with UV as a standalone process and under photocatalytic conditions with $\mathrm{UV} / \mathrm{S}-\mathrm{TiO}_{2}$ and $\mathrm{UV} / 0.5 \mathrm{Pd} 120$ : $\mathrm{H}_{2}$ and $\mathrm{CH}_{4}$ production a), $\mathrm{H}_{2} / \mathrm{CO}_{2}$ molar ratio b) and $\mathrm{CH}_{4}$ production $\mathrm{c}$ ).

accumulate on the surface of $\mathrm{Pd}$ and excessive positive charges accumulate on the surface of $\mathrm{TiO}_{2}$. Therefore, the energy band of $\mathrm{TiO}_{2}$ bends upwards, forming the Schottky barrier. Therefore, in the composite catalyst, Pd acts as an electron trap, which can effectively prevent the surface electron-hole recombination [43].

The value of the $\mathrm{H}_{2} / \mathrm{CO}_{2}$ molar ratio did not change significantly as irradiation time increased, tending to a value approximately equal to 2 after three hours of irradiation (Fig. 7b). $\mathrm{CO}_{2}$ and $\mathrm{H}_{2}$ are mainly produced from the photocatalytic wet reforming of glucose, according to the following reaction (Eq. 1):

$$
\mathrm{C}_{6} \mathrm{H}_{12} \mathrm{O}_{6}(l)+6 \mathrm{H}_{2} \mathrm{O}(l)=6 \mathrm{CO}_{2}(g)+12 \mathrm{H}_{2}(g)
$$




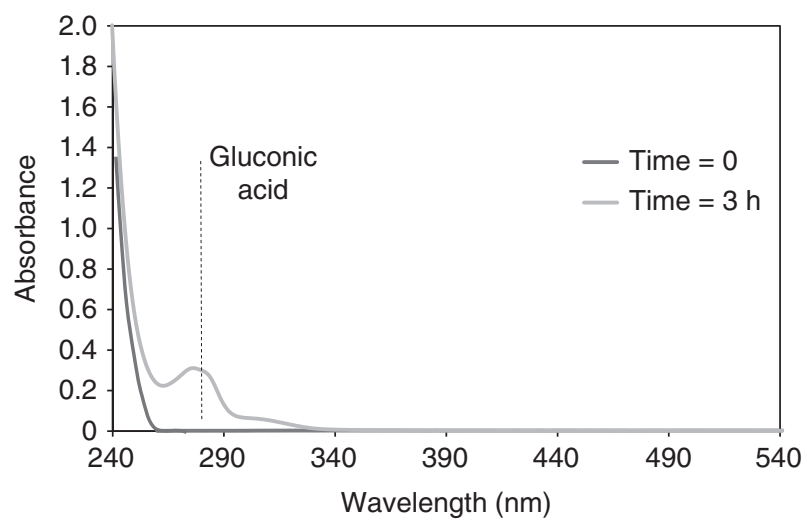

Figure 8

Spectrophotometric analysis of the aqueous solution before and after treatment with the $0.5 \mathrm{Pd} 120$ catalyst.

The deposition of $\mathrm{Pd}(0.5 \mathrm{Pd} 120)$ resulted in an increased methane production $(7.58 \mu \mathrm{mol})$ and yield $(2 \%)$ compared with the $\mathrm{S}-\mathrm{TiO}_{2}$ catalyst, for which $\mathrm{CH}_{4}$ production and yield were about $2.8 \mu \mathrm{mol}$ and $0.6 \%$, respectively (Fig. $7 \mathrm{c}$ ).

In the absence of oxygen, methane could result from the degradation of glucose through the following reaction (Eq. 2) [44]:

$$
\mathrm{C}_{6} \mathrm{H}_{12} \mathrm{O}_{6}(l)=3 \mathrm{CH}_{4}(g)+3 \mathrm{CO}_{2}(g)
$$

Since $\mathrm{CO}_{2}$ mainly comes from the photocatalytic wet reforming of glucose (Eq. 1), as confirmed by the molar ratio $\mathrm{H}_{2} / \mathrm{CO}_{2}$ being equal to $2, \mathrm{CH}_{4}$ could be formed through the following reaction (Eq. 3), similar to anaerobic digestion:

$$
\mathrm{C}_{6} \mathrm{H}_{12} \mathrm{O}_{6}(l)+6 \mathrm{H}_{2} \mathrm{O}(l)=6 \mathrm{CH}_{4}(g)+6 \mathrm{O}_{2}(g)
$$

This result is confirmed by the analysis of the liquid phase after 3 hours of irradiation, which showed the presence of gluconic acid (Fig. 8), a typical product of glucose oxidation [45]. Therefore, the oxygen produced according to Equation (3) possibly reacts with glucose, leading to the formation of gluconic acid. The presence of the latter was detected by spectrophotometric analysis of the liquid sample whose result is reported in Figure 8; gluconic acid is represented by a band with a peak at a wavelength of $254 \mathrm{~nm}$ [45]. The presence of any intermediate compounds that have been produced by the oxidation of glucose, such as gluconic acid, is important because they may possibly be recovered and used for different purposes (food, pharmaceutical and hygienic products) [45].

Glucose conversions observed during $\mathrm{S}-\mathrm{TiO}_{2}$ and $\mathrm{Pd}-\mathrm{TiO}_{2}$ photocatalytic treatment after 3 hours of irradiation are shown in Figure 9. The photocatalytic activity of

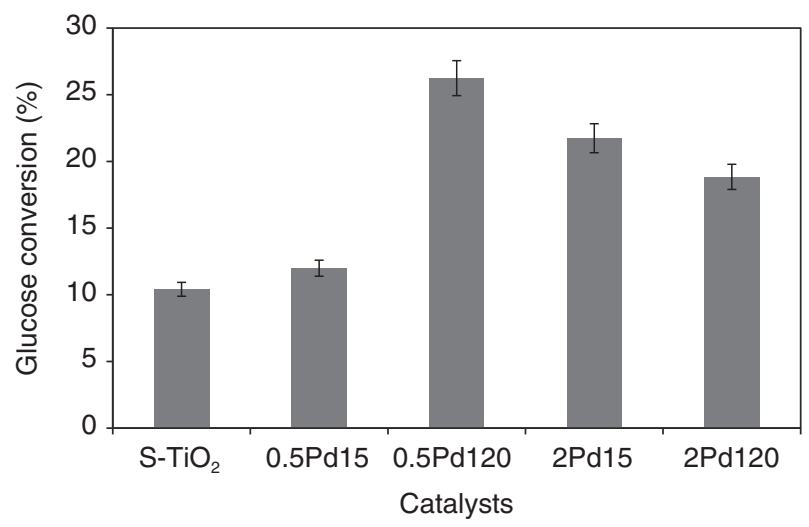

Figure 9

Glucose conversion after photocatalytic treatment by $\mathrm{S}-\mathrm{TiO}_{2}$ and $\mathrm{Pd}-\mathrm{TiO}_{2}$ catalysts ( $3 \mathrm{~h}$ irradiation time).

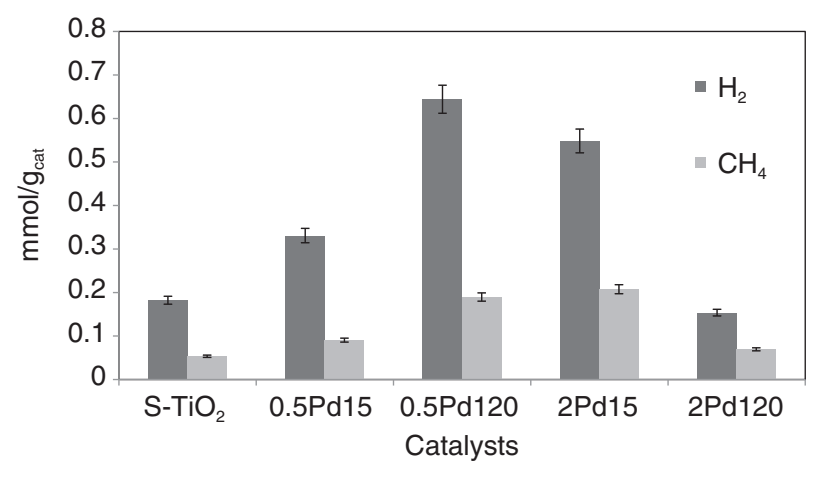

Figure 10

$\mathrm{H}_{2}$ and $\mathrm{CH}_{4}$ production after photocatalytic treatment by $\mathrm{S}-\mathrm{TiO}_{2}$ and $\mathrm{Pd}-\mathrm{TiO}_{2}$ catalysts ( $3 \mathrm{~h}$ irradiation time).

$\mathrm{Pd}-\mathrm{TiO}_{2}$ was influenced by the photodeposition time and by the content of palladium used in the synthesis of the photocatalysts. The increase in the photodeposition time up to $120 \mathrm{~min}$ had a positive effect on the $\mathrm{TiO}_{2}$ photoactivity for $0.5 \mathrm{wt} \%$ of Pd loading. Glucose conversion values obtained with the catalysts with $2 \mathrm{wt} \%$ of Pd content were lower than those obtained with the catalysts with $0.5 \mathrm{wt} \%$ of Pd loading, for both deposition times investigated. In particular, the best catalyst for the conversion of glucose was $0.5 \mathrm{Pd} 120$, for which the glucose conversion was as high as $26 \%$.

This result is in agreement with the production of hydrogen and methane (Fig. 10); the highest production of $\mathrm{H}_{2}$ and $\mathrm{CH}_{4}$ was observed for the catalyst $0.5 \mathrm{Pd} 120$. In particular, on this catalyst it is possible to obtain $0.65 \mathrm{mmol} / \mathrm{g}_{\text {cat }}$ of $\mathrm{H}_{2}$ and $0.18 \mathrm{mmol} / \mathrm{g}_{\text {cat }}$ of $\mathrm{CH}_{4}$.

It is very important to note that the hydrogen production is very similar to that obtained by using a UV lamp with a nominal power of $125 \mathrm{~W}$ [29]. 


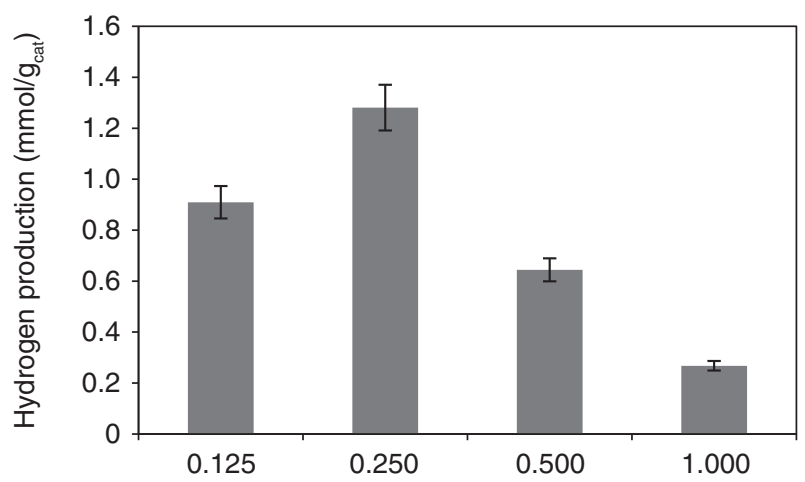

a)

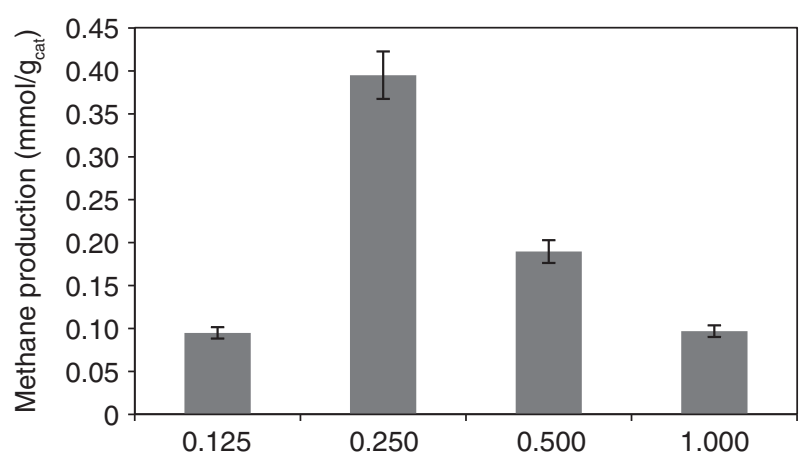

b)

Catalyst dosage $(\mathrm{g} / \mathrm{L})$

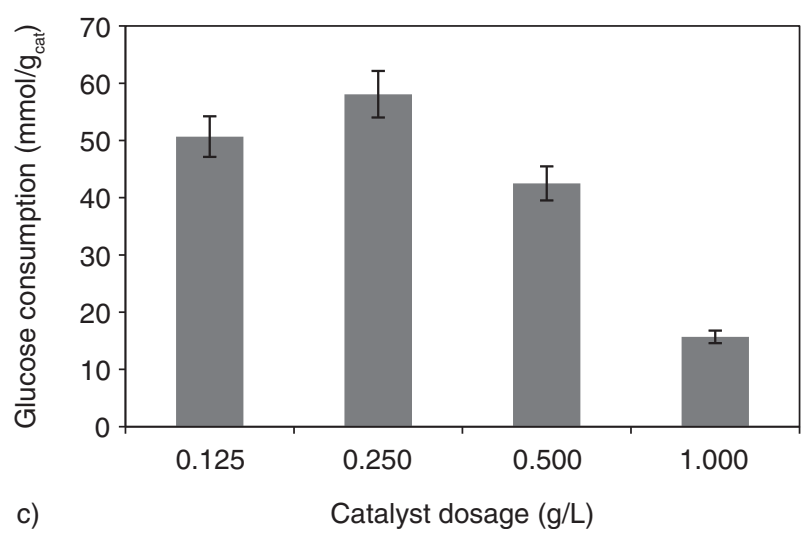

Figure 11

Optimization of catalyst loading according to hydrogen a) and methane $b$ ) production, and glucose consumption c).
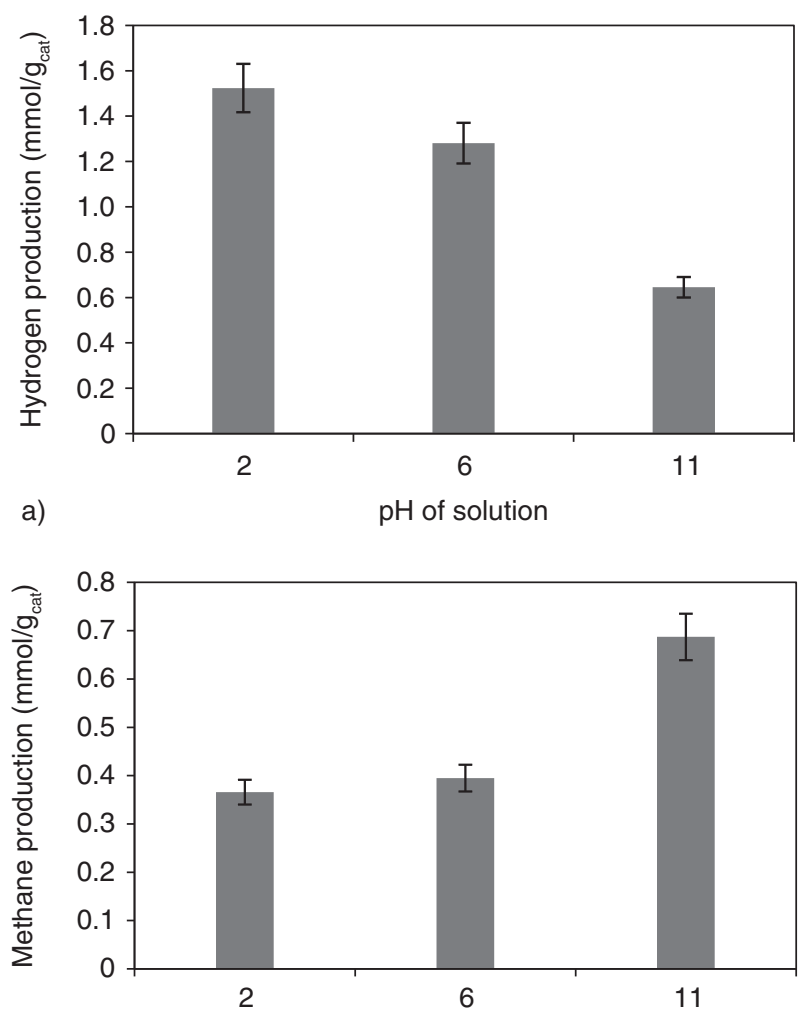

b)

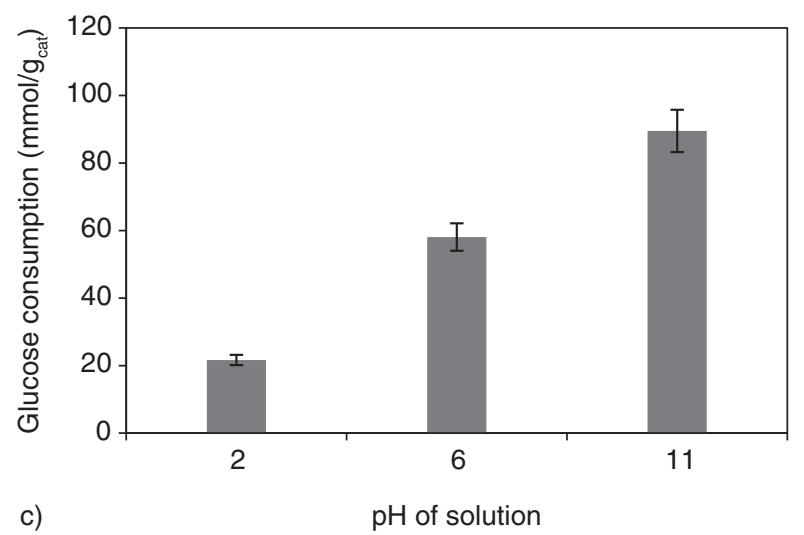

Figure 12

Effect of the initial $\mathrm{pH}$ on hydrogen a) and methane b) production, and glucose consumption c).
The behavior observed could be explained taking into account that in the analyzed photocatalysts partially oxidized Pd species and metallic Pd were detected. These species could be responsible for the differences observed in the glucose conversion and hydrogen production in the glucose reforming over $\mathrm{Pd}-\mathrm{TiO}_{2}$ photocatalysts. The catalyst prepared with $0.5 \mathrm{wt} \%$ Pd loading and $120 \mathrm{~min}$ of photodeposition time resulted in the highest glucose conversion and $\mathrm{H}_{2}$ production. The highest performances are possibly related to a homogeneous Pd nanoparticle distribution over the $\mathrm{TiO}_{2}$ surface with sizes lower than $4 \mathrm{~nm}$ (as observed by TEM analysis) and $\mathrm{Pd}^{0}$ oxidation state (according to XPS analysis, metal preferentially occurs in its metallic state $\left(\mathrm{Pd}^{0}\right)$ ).

For the catalysts with a Pd content higher than $0.5 \mathrm{wt} \%$, the presence of $\mathrm{Pd}^{\delta+}$ species on the $\mathrm{TiO}_{2}$ surface could induce a preferential Pd photodeposition on these species, 
not over $\mathrm{TiO}_{2}$, leading to an increase in the Pd particle size. Moreover, the metal oxidation state can modify the adsorption of glucose on the photocatalyst surface, thus determining a different catalytic activity.

\subsubsection{Optimization of Catalyst Dosage for Photocatalytic Tests}

The optimization of the catalyst dosage was carried out under UV irradiation by testing different concentrations of $0.5 \mathrm{Pd} 120$ photocatalysts, in the range $0.125-1 \mathrm{~g} / \mathrm{L}$. Photocatalytic efficiency increased as catalyst loading was increased up to $0.25 \mathrm{~g} / \mathrm{L}$. As catalyst loading was further increased, the conversion of glucose and the simultaneous formation of $\mathrm{H}_{2}$ and $\mathrm{CH}_{4}$ decreased (Fig. 11).

Possibly, the increase in the catalyst dosage over the optimum value resulted in a decreased light penetration through the solution because of the increased opacity of the aqueous suspension [46].

\subsubsection{Influence of Initial pH of Solution}

Finally, the effect of the $\mathrm{pH}$ on the production of hydrogen (Fig. 12a) and methane (Fig.12b) as well as on the conversion of glucose (Fig. 12c) was evaluated. The specific conversion of glucose increased as the solution $\mathrm{pH}$ was increased. The effects of $\mathrm{pH}$ on hydrogen generation are considered to be quite complex, involving the changes of the chemical state of glucose, redox potential of $\mathrm{H}^{+} / \mathrm{H}_{2}$ and relative position of the band edges of the semiconductor [47]. At lower $\mathrm{pH}$ values $(\mathrm{pH}=3)$, the redox potential of $\mathrm{H}^{+} / \mathrm{H}_{2}$ would become more positive, which is advantageous for efficient hydrogen generation [47]. However, the most favorable condition for methane production is alkaline solution. Accordingly, the highest methane production was observed at $\mathrm{pH} 11$ (about twice that at $\mathrm{pH} 3$ ). Possibly, when the redox potential of $\mathrm{H}^{+} / \mathrm{H}_{2}$ becomes more negative and the $\mathrm{pH}$ of the solution is similar to the $\mathrm{pk}_{\mathrm{a}}$ of glucose, the methane production is enhanced.

\section{CONCLUSIONS}

Pd deposition onto the sulfated $\mathrm{TiO}_{2}$ surface throughout the photodeposition time was favorable to the production of $\mathrm{H}_{2}$ or $\mathrm{CH}_{4}$ by photocatalysis. These compounds were produced efficiently by photocatalytic reforming of aqueous solutions of glucose. The experimental conditions during photodeposition, such as deposition time, were found to have a strong influence on the final properties of the materials, and consequently on their photocatalytic activity in glucose reforming. A short deposition time (15 min) led to a smaller average particle size and higher dispersion of the palladium on the sulfated $\mathrm{TiO}_{2}$ surface, as well as a higher fraction of the metal in its metallic state. These features resulted in a good photocatalytic performance in terms of glucose conversion. The best photocatalytic behavior was observed in the sample prepared with $0.5 \mathrm{wt} \%$ of palladium and $120 \mathrm{~min}$ of photodeposition time. By changing the $\mathrm{pH}$ of the solution, it is possible to modulate the performance of the photocatalytic reaction, producing more methane in alkaline conditions or more hydrogen in acidic conditions.

The process appears to be a promising, cost-effective method (also considering the high energy-efficiency lighting by UVA-LED) for the treatment of sugar water from industrial food processes, with a parallel recovery of products $\left(\mathrm{CH}_{4}\right.$ and $\left.\mathrm{H}_{2}\right)$ which could be successfully used for energy production.

\section{ACKNOWLEDGMENTS}

J.J. Murcia would like to thank the CSIC for the concession of a JAE grant. CITIUS (University of Seville) is acknowledged for XPS and XRF measurements.

Diana Sannino wishes to thank the University of Salerno for funding the project "ORSA111873; Processi chimici catalitici per la produzione di energia sostenibile e l'ambiente".

\section{REFERENCES}

1 Turner J.A. (2004) Sustainable Hydrogen Production, Science 305, 5686, 972-974.

2 Fu X., Long J., Wang X., Leung D.Y.C., Ding Z., Wu L., Zhang Z., Li Z., Fu X. (2008) Photocatalytic reforming of biomass: A systematic study of hydrogen evolution from glucose solution, International Journal of Hydrogen Energy 33, 22, 6484-6491.

3 Kondarides D.I., Patsoura A., Verykios X.E. (2010) Anaerobic Photocatalytic Oxidation of Carbohydrates in Aqueous $\mathrm{Pt} / \mathrm{TiO}_{2}$ Suspensions with Simultaneous Production of Hydrogen, J. Adv. Oxid. Technol. 13, 1, 116-123.

4 Azadi P., Otomo J., Hatano H., Oshima Y., Farnood R. (2010) Hydrogen production by catalytic near-critical water gasification and steam reforming of glucose, International Journal of Hydrogen Energy 35, 8, 3406-3414.

5 Bičáková O., Straka P. (2012) Production of hydrogen from renewable resources and its effectiveness, International Journal of Hydrogen Energy 37, 16, 11563-11578.

6 Moreno T., Kouzaki G., Sasaki M., Goto M., Cocero M.J. (2012) Uncatalysed wet oxidation of d-glucose with hydrogen peroxide and its combination with hydrothermal electrolysis, Carbohydrate Research 349, 33-38.

7 Prüße U., Herrmann M., Baatz C., Decker N. (2011) Goldcatalyzed selective glucose oxidation at high glucose concentrations and oxygen partial pressures, Applied Catalysis A: General 406, 1-2, 89-93.

8 Foster A.J., Jae J., Cheng Y.-T., Huber G.W., Lobo R.F. (2012) Optimizing the aromatic yield and distribution from catalytic fast pyrolysis of biomass over ZSM-5, Applied Catalysis A: General 423-424, 154-161. 
9 Hallenbeck P.C., Abo-Hashesh M., Ghosh D. (2012) Strategies for improving biological hydrogen production, Bioresource Technology 110, 1-9.

10 Ntaikou I., Gavala H.N., Kornaros M., Lyberatos G. (2008) Hydrogen production from sugars and sweet sorghum biomass using Ruminococcus albus, International Journal of Hydrogen Energy 33, 4, 1153-1163.

11 Lee H.S., Salerno M.B., Rittmann B.E. (2008) Thermodynamic evaluation on $\mathrm{H}_{2}$ production in glucose fermentation, Environmental Science \& Technology 42, 7, 2401-2407.

12 McGinley J., McHale F.N., Hughes P., Reid C.N., McHale A.P. (2004) Production of electrical energy from carbohydrates using a transition metal-catalysed liquid alkaline fuel cell, Biotechnology Letters 26, 23, 1771-1776.

13 Kawai T., Sakata T. (1980) Conversion of carbohydrate into hydrogen fuel by a photocatalytic process, Nature 286, 5772 , 474-476.

14 Bahruji H., Bowker M., Davies P.R., Al-Mazroai L.S., Dickinson A., Greaves J., James D., Millard L., Pedrono F. (2010) Sustainable $\mathrm{H}_{2}$ gas production by photocatalysis, Journal of Photochemistry and Photobiology A: Chemistry 216, 2-3, 115-118.

15 Song C. (2002) Fuel processing for low-temperature and hightemperature fuel cells: Challenges, and opportunities for sustainable development in the $21^{\text {st }}$ century, Catal. Today 77 , $1-2,17-49$.

16 Hamelinck C.N., Faaij A.P.C. (2002) Future prospects for production of methanol and hydrogen from biomass, Journal of Power Sources 111, 1, 1-22.

17 Bridgwater A.V. (1994) Catalysis in thermal biomass conversion, Applied Catalysis A: General 116, 1-2, 5-47.

18 Huber G.W., Shabaker J.W., Dumesic J.A. (2003) Raney Ni-Sn catalyst for $\mathrm{H}_{2}$ production from biomass-derived hydrocarbons, Science 300, 5628, 2075-2077.

19 Vaiano V., Sacco O., Sannino D., Ciambelli P., Longo S., Venditto V., Guerra G. (2014) N-doped $\mathrm{TiO}_{2} / \mathrm{s}$-PS aerogels for photocatalytic degradation of organic dyes in wastewater under visible light irradiation, J. Chem. Technol. Biotechnol. 89, 8, 1175-1181.

20 Vaiano V., Sacco O., Stoller M., Chianese A., Ciambelli P., Sannino D. (2014) Influence of the photoreactor configuration and of different light sources in the photocatalytic treatment of highly polluted wastewater, Int. J. Chem. React. Eng. 12, 1, 1-13.

21 Mohamed R.M., Aazam E.S. (2012) $\mathrm{H}_{2}$ Production with Low CO Selectivity from Photocatalytic Reforming of Glucose on $\mathrm{Ni} / \mathrm{TiO}_{2}-\mathrm{SiO}_{2}$, Chinese Journal of Catalysis 33, 2-3, 247-253.

22 Gomathisankar P., Yamamoto D., Katsumata H., Suzuki T., Kaneco S. (2013) Photocatalytic hydrogen production with aid of simultaneous metal deposition using titanium dioxide from aqueous glucose solution, International Journal of Hydrogen Energy 38, 14, 5517-5524.

23 Zhang L., Shi J., Liu M., Jing D., Guo L. (2014) Photocatalytic reforming of glucose under visible light over morphology controlled $\mathrm{Cu}_{2} \mathrm{O}$ : Efficient charge separation by crystal facet engineering, Chemical Communications 50, 2, 192-194.

24 Carraro G., Maccato C., Gasparotto A., Montini T., Turner S., Lebedev O.I., Gombac V., Adami G., Van Tendeloo G., Barreca D., Fornasiero P. (2014) Enhanced Hydrogen Production by Photoreforming of Renewable Oxygenates Through Nanostructured $\mathrm{Fe}_{2} \mathrm{O}_{3}$ Polymorphs, Advanced Functional Materials 24, 3, 372-378.
25 Kondarides D., Daskalaki V., Patsoura A., Verykios X. (2008) Hydrogen Production by Photo-Induced Reforming of Biomass Components and Derivatives at Ambient Conditions, Catal Lett. 122, 1-2, 26-32.

26 Linsebigler A.L., Lu G., Yates J.T. (1995) Photocatalysis on $\mathrm{TiO}_{2}$ Surfaces: Principles, Mechanisms, and Selected Results, Chemical Reviews 95, 3, 735-758.

27 Chong R., Li J., Ma Y., Zhang B., Han H., Li C. (2014) Selective conversion of aqueous glucose to value-added sugar aldose on $\mathrm{TiO}_{2}$-based photocatalysts, Journal of Catalysis 314, 101-108.

28 Wu G., Chen T., Zhou G., Zong X., Li C. (2008) $\mathrm{H}_{2}$ production with low $\mathrm{CO}$ selectivity from photocatalytic reforming of glucose on metal $/ \mathrm{TiO}_{2}$ catalysts, Sci. China Ser. B-Chem. 51, 2, 97-100.

29 Colmenares J.C., Magdziarz A., Aramendia M.A., Marinas A., Marinas J.M., Urbano F.J., Navio J.A. (2011) Influence of the strong metal support interaction effect (SMSI) of $\mathrm{Pt} / \mathrm{TiO}_{2}$ and $\mathrm{Pd} / \mathrm{TiO}_{2}$ systems in the photocatalytic biohydrogen production from glucose solution, Catalysis Communications 16, 1, 1-6.

30 Passio L., Rizzoa L., Fuchs S. (2012) Two-phase anaerobic digestion of partially acidified sewage sludge: a pilot plant study for safe sludge disposal in developing countries, Environmental technology 33, 16-18, 2089-2095.

31 Li Y., Park S.Y., Zhu J. (2011) Solid-state anaerobic digestion for methane production from organic waste, Renewable and Sustainable Energy Reviews 15, 1, 821-826.

32 Sakata T., Kawai T. (1981) Heterogeneous photocatalytic production of hydrogen and methane from ethanol and water, Chemical Physics Letters 80, 2, 341-344.

33 Colón G., Hidalgo M.C., Navío J.A. (2003) Photocatalytic behaviour of sulphated $\mathrm{TiO}_{2}$ for phenol degradation, Applied Catalysis B 45, 1, 39-50.

34 Maicu M., Hidalgo M.C., Colón G., Navío J.A. (2011) Comparative study of the photodeposition of $\mathrm{Pt}, \mathrm{Au}$ and $\mathrm{Pd}$ on pre-sulphated $\mathrm{TiO}_{2}$ for the photocatalytic decomposition of phenol, Journal of Photochemistry and Photobiology A: Chemistry 217, 2-3, 275-283.

35 Hidalgo M.C., Murcia J.J., Navío J.A., Colón G. (2011) Photodeposition of gold on titanium dioxide for photocatalytic phenol oxidation, Applied Catalysis A: General 397, 1-2, 112-120.

36 Murcia J.J., Hidalgo M.C., Navío J.A., Araña J., DoñaRodríguez J.M. (2014) Correlation study between photodegradation and surface adsorption properties of phenol and methyl orange on $\mathrm{TiO}_{2}$ Vs platinum-supported $\mathrm{TiO}_{2}$, Applied Catalysis B 150-151, 107-115.

37 DuBois M., Gilles K.A., Hamilton J.K., Rebers P.A., Smith F. (1956) Colorimetric Method for Determination of Sugars and Related Substances, Analytical Chemistry 28, 3, 350-356.

38 Albalasmeh A.A., Berhe A.A., Ghezzehei T.A. (2013) A new method for rapid determination of carbohydrate and total carbon concentrations using UV spectrophotometry, Carbohydrate Polymers 97, 2, 253-261.

39 Navaladian S., Viswanathan B., Varadarajan T.K., Viswanath R.P. (2008) A Rapid Synthesis of Oriented Palladium Nanoparticles by UV Irradiation, Nanoscale Research Letters 4, 2, 181-186.

40 Brun M., Berthet A., Bertolini J.C. (1999) XPS, AES and Auger parameter of Pd and PdO, Journal of Electron Spectroscopy and Related Phenomena 104, 1-3, 55-60. 
41 Siemon U., Bahnemann D., Testa J.J., Rodríguez D.Litter M.I. Bruno N. (2002) Heterogeneous photocatalytic reactions comparing $\mathrm{TiO}_{2}$ and $\mathrm{Pt} / \mathrm{TiO}_{2}$, Journal of Photochemistry and Photobiology A: Chemistry 148, 1-3, 247-255.

42 Bamwenda G.R., Tsubota S., Nakamura T., Haruta M. (1995) Photoassisted hydrogen production from a water ethanol solution a comparison of activities of $\mathrm{Au}-\mathrm{TiO}_{2}$ and $\mathrm{Pt}-\mathrm{TiO}_{2}$, Journal of Photochemistry and Photobiology A: Chemistry 89, 2, 177-189.

43 Liu Y., Guo L., Yan W., Liu H. (2006) A composite visible-light photocatalyst for hydrogen production, Journal of Power Sources 159, 2, 1300-1304.

44 Kenney J.F., Kutcherov V.A., Bendeliani N.A., Alekseev V.A. (2002) The evolution of multicomponent systems at high pressures: VI. The thermodynamic stability of the hydrogen-carbon system: The genesis of hydrocarbons and the origin of petroleum, Proceedings of the National Academy of Sciences 99, 17, 10976-10981.
45 Ramachandran S., Fontanille P., Pandey A., Larroche C. (2006) Gluconic acid: Properties, applications and microbial production, Food Technology and Biotechnology 44, 2, 185-195.

46 Sannino D., Vaiano V., Sacco O., Ciambelli P. (2013) Mathematical modelling of photocatalytic degradation of methylene blue under visible light irradiation, Journal of Environmental Chemical Engineering 1, 1-2, 56-60.

47 Jing D., Liu M., Shi J., Tang W., Guo L. (2010) Hydrogen production under visible light by photocatalytic reforming of glucose over an oxide solid solution photocatalyst, Catalysis Communications 12, 4, 264-267.

Manuscript submitted in October 2014 Manuscript accepted in December 2014 Published online in March 2015

Cite this article as: V. Vaiano, G. Iervolino, G. Sarno, D. Sannino, L. Rizzo, J.J.M. Mesa, M.C. Hidalgo and J.A. Navío (2015). Simultaneous Production of $\mathrm{CH}_{4}$ and $\mathrm{H}_{2}$ from Photocatalytic Reforming of Glucose Aqueous Solution on $\mathrm{Sulfated} \mathrm{Pd}-\mathrm{TiO}_{2}$ Catalysts, Oil Gas Sci. Technol 70, 5, 891-902. 